unattained limiting value is not new-fangled, it appears worth while to quote a few words of the paper of Gauss, above referred to, which is of date 1799 .

" Ex suppositione, X obtinere posse valorem $\mathrm{S}$ neque vero valorem $\Pi$, nondum sequitur, inter $S$ et $\Pi$ necessario valorem $T$ jacere, quem X attingere sed non superare possit. Superest adhuc alius casus : scilicet fieri posset, ut inter $S$ et $\Pi$ limes situs sit, ad quem accedere quidem quam prope velis possit $\mathrm{X}$, ipsum vero nihilominus nunquam attingere."

It is a curious enough fact of history that it is Weierstrass's use of this principle which has destroyed the Dirichlet proof of a fundamental theorem of the theory of potential (Thomson and Tait's " Natural Philosophy," I879, vol. i., first line of p. I7 I).

Cambridge, January 23.

The Aurora of September 9, 1898.

I OBSERVE, from NATURE, that an auroral display was visible in the South of England on the evening of September 9. It may interest some of your readers to know that an aurora was seen here on the evening of September Io. The display began at about a quarter to eight o'clock, and lasted for an hour or so. The whole southern heavens at first became suffused with a bright orange light low down upon the horizon, from which a $\mathrm{f}$ ew streamers issued from time to time, rising (judging by the eye) to a height of, say, 45 degrees above the horizon. When both glow and streamers had faded away, I noticed three luminous clouds, one at the zenith. The largest of these clouds increased in size, and shot forth a few streamers of light, both upwards and downwards, and all then disappeared. I have witnessed several auroral displays at Ashburton, but none like that of September Io, the distinguishing features of which were the orange glow and the luminous clouds.

On the following day, my telephone, which had never failed me before, worked irregularly, and some of the other telephones in the town were similarly affected. Chas. W. PURnill.

Ashburton, Canterbury, N.Z., December 2I, 1898.

\section{THE APPLICATION OF PHOTOGRAPHY TO THE STUDY OF THE MANOMETRIC FLAME.}

THERE are few more beautiful phenomena in experimental physics than those presented by the image of the manometric flame as one sees it in the revolving mirror. Especially is this true when the flame is excited by means of the complex tones of the human voice or by some musical instrument such as the violin, which possesses pronounced and varying tone colour.

Little use, nevertheless, has been made of the flame as an implement in research. Indeed the whole of the early literature pertaining to the manometric flame may be said to consist of the three papers ${ }^{1}$ in which, at intervals of ten years, Rudolph Koenig described the apparatus which he first made public at the London Exhibition of 1862 , together with the various experiments to which it was adapted. The writers of text-books, it is true, have made free use of Koenig's beautiful method, but investigators have been slow to avail themselves of it. The use of sensitive flames in the stroboscopic study of vibrations by Toepler (Poggendorf's Annalen, vol. cxxviii. p, I08, 1866), which method has since been employed by Brockmann (Wiedemann's Annalen, vol. xxxi. p. 78 , I887) in his analysis of the movement of the air in organpipes, and also the observations of singing and of sensitive flames by Kundt (Poggendorff's Annalen, vol. cxxviii. p. 337 and p. 614, 1866); by Barrett (Philosophical Magazine, I867); and by Tyndall ("On Sound," Lecture vi., 1867), belong to this period. These researches, however, form a class by themselves, and are to be traced back to the earlier work of Higgins (I777), Chladin (1802), De la Rive (I802), Faraday (1818), Wheatstone (1832), Schaffgotsch (1857), and Le Conte

1 Koenig: Poggendorft's Annalen, vol. cxxii. p. 242 ; vol. cxlvi. p. I6I ; "Quelques Experiences d'Acoustique," Chapter vii. NO. I 527 , VOL. 59]
(1858). In them the use of the manometric capsule does not occur, and they appear, from first to last, to be entirely independent of the work of Koenig.

The difficulty of securing a trustworthy record of the forms taken on by the flame-image has doubtless had much to do with this hesitancy. The drawings published by Koenig to accompany the description of his experiments are of great beauty, and the more intimately one is acquainted with the appearance of the flame-image itself, the more one is impressed with the extraordinary fidelity of these representations of it. The secret of their accuracy is to be found in the method by which they were obtained, which is described by Koenig in the article of 1872 , to which reference has already been made. In the preparation of the well-known plate of the drawings of flame-images corresponding to the five principal vowel sounds, which was exhibited at the annual meeting of German Men of Science (Naturforscherversamminus, Dresden, 1868) each vowel was sung at a carefully ascertained pitch, and duplicate drawings were made by Koenig himself and by a draughtsman employed for that purpose. When these two drawings were found to be alike they were assumed to be correct, but wherever a variation occurred the experiment was repeated until the two were brought into agreement. Each vowel was sounded with a pitch corresponding to each note of the scale between $u t_{1}$ and $u t_{3}$, so that seventy-five of these drawings, perfected by many repetitions, appear in this one plate.

The most complicated of the pictures of the manometric flame drawn by Koenig is that shown in Fig. ?,

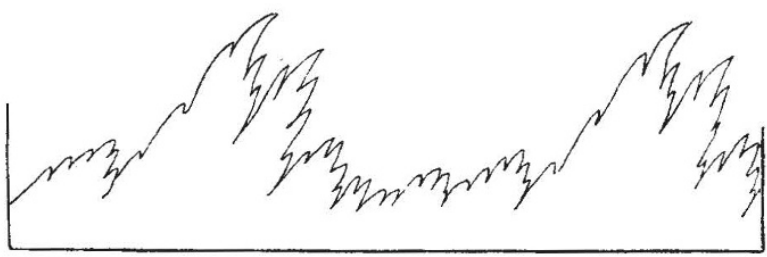

FIG. I.-Drawing of a manometric flame (after Koenig).

in which an attempt is made to record the motions of the flame when the tongue is going through the vibrations necessary to produce the rolling sound of the German $r$, but without permitting the vowel-producing qualities of the voice to accompany it. Doubtless the difficulty of securing records by the method of free-hand sketching, which had been employed by Koenig, to say nothing of the difficulty of interpreting the more complicated forms assumed by the flame-image, has prevented the general introduction of what in other respects is a very attractive method of research.

In 1886 the question, which must have occurred to many observers of the manometric flame, whether these fleeting flame-images could be photographed, was answered affirmatively by Doumer (Comptes rendus, vol. ciii. p. 340 ; vol. cv. p. I247), who used such photographs in the determination of pitch and of the phase relations of sound waves. Doumer, however, published none of his photographs; so that we do not know what degree of success he attained. In 1893 Merritt, who was at that time unacquainted with Doumer's experiments, undertook the photography of the manometric flame in the hope of thus developing a method which would be of use in connection with certain studies in phonetics. His paper, entitled "A Method of Photographing the Manometric Flame, with Applications to the Study of the Vowel A" (Physical Review, vol. i. p. I66), contains the first published photographs of the Koenig flame-images. Merritt found it barely possible to photograph, upon a rapidly moving plate, the flame produced by the ordinary Koenig apparatus. The actinic weakness of the flame 